\title{
Pembuatan Toko Online Produk-Produk Khas di Kawasan Menoreh Kulonprogo
}

\author{
Imam Fahrurrozi ${ }^{*}$, Muhammad Rifqi Al Fauzan ${ }^{2}$, Tika Erna Putri ${ }^{3}$, Rendra Dwi \\ Firmansyah ${ }^{4}$, Ronald Adrian, ${ }^{5}$, Atikah Suriani ${ }^{6}$. \\ ${ }^{1}$ Program Studi Komputer dan Sistem Informasi, Departemen Teknik Elektro dan \\ Informatika, Sekolah Vokasi, Universitas Gadjah Mada \\ ${ }^{2}$ Program Studi Metrologi dan Instrumentasi, Departemen Teknik Elektro dan Informatika, \\ Sekolah Vokasi, Universitas Gadjah Mada \\ 3,4 Program Studi Elektronika dan Instrumentasi, Departemen Teknik Elektro dan \\ Informatika, Sekolah Vokasi, Universitas Gadjah Mada \\ ${ }_{5}^{5}$ Program Studi Teknologi Jaringan, Departemen Teknik Elektro dan Informatika, Sekolah \\ Vokasi, Universitas Gadjah Mada \\ ${ }^{6}$ Program Studi Teknik Elektro, Departemen Teknik Elektro dan Informatika, Sekolah \\ Vokasi, Universitas Gadjah Mada \\ *Email: imam.fahrurrozi@ugm.ac.id
}

\begin{abstract}
Abstrak
Salah satu kegiatan pengabdian kepada masyarakat Sekolah Vokasi UGM ini bertujuan untuk membuat Toko Online produk-produk khas di kawasan Menoreh Kecamatan Samigaluh Kabupaten Kulon Progo. Menoreh merupakan kawasan yang sangat potensial bukan hanya karena sumber daya alamnya, hal itu dibuktikan dengan adanya dukungan pemerintah melalui Kementerian Pariwisata yang menetapkan Menoreh sebagai Kawasan Strategis Pariwisata Nasional (KSPN) Borobudur. Kawasan Menoreh juga menyimpan banyak potensi wisata yang masih belum berkembang dengan baik. Tidak banyak informasi yang dapat diperoleh dari internet mengenai wisata di Menoreh, terutama tentang produk-produk asli Kawasan Menoreh seperti kripik pegagang, kopi suroloyo dan masih banyak produk-produk yang lain. Maka perlu adanya Toko Online khusus berbasis Web untuk mempromosikan produk-produk tersebut sehingga meningkatkan informasi dan penjualan produk-produk asli kawasan tersebut. Selain membuat Toko Online produk-produk khas Kawasan menorah, kegiatan pengabdian kepada masyarakat ini juga mengadakan pelatihan bagi para admin yang ada di tiap-tiap desa yang ada di Kawasan Menoreh. Hasilnya produk-produk khas Kawasan menorah dapat diakses di halaman URL : produk.menoreh.org dan tiap-tiap desa mempunyai seorang admin yang bertanggung-jawab dalam promosi produk-produk asli dari desanya masing-masing.
\end{abstract}

Kata Kunci: kawasan menoreh, toko online, produk-produk khas

\begin{abstract}
One of the activities of dedication to the community of Vocational School UGM aims to create an Online Store of typical products in Menoreh area, Samigaluh District, Kulon Progo Regency. Menoreh is a very potential area not only because of its natural resources, it is proved by the existence of government support through the Ministry of Tourism which establish Menoreh as the National Tourism Strategic Area (KSPN) Borobudur. Menoreh area also save a lot of tourism potential that is still not well developed. Not much information can be obtained from the internet about tours in Menoreh, especially about the original products of Menoreh area such as the chips of the merchant, suroloyo coffee and many other products. So need a special Web-based Online Store to promote these products so as to improve the information and sales of original products of the region. In addition to making the Online Store products typical of the Menorah area, community service activities also provide training for the admin in each village in Menoreh area. As a result the typical products of the Menorah area can be accessed on the URL page:
\end{abstract}


produk.menoreh.org and each village has an admin who is responsible for the promotion of original products from their respective villages.

Keywords: menoreh area, online store, typical products.

\section{PENDAHULUAN}

Kulon Progo merupakan salah satu Kabupaten di wilayah Provinsi Daerah Istimewa Yogyakarta. Kabupaten ini berbatasan dengan Kabupaten Sleman dan Kabupaten Bantul di timur, Samudra Hindia di selatan, Kabupaten Purworejo di barat, serta Kabupaten Magelang di utara. Kabupaten Kulon Progo terdiri atas 12 kecamatan, yang dibagi lagi atas 88 desa dan kelurahan, serta 930 Pedukuhan (sebelum otonomi daerah dinamakan Dusun). Pusat pemerintahan di Kecamatan Wates, yang berada sekitar $25 \mathrm{~km}$ sebelah barat daya dari pusat Ibukota Provinsi Yogyakarta. Bagian barat laut wilayah kabupaten ini berupa perbukitan Menoreh, dengan puncaknya puncak Suroloyo (1019 m), di perbatasan dengan Kabupaten Magelang. Kawasan Menoreh ini dijadikan prioritas untuk kegiatan pengabdian Sekolah Vokasi Universitas Gadjah Mada tahun 2017. Salah satu wilayah yang dilewati jalur perbukitan Menoreh adalah Kecamatan Samigaluh. Di kawasan ini pula akan dibangun jalur yang menghubungkan Bandara New Yogyakarta International Airport (NYIA) dengan Candi Borobudur. Oleh karena itu Samigaluh menjadi Kawasan Strategis Pariwisata Nasional (KSPN) Borobudur. Pengabdian ini berfokus pada desa-desa di kawasan Menoreh sesuai hasil rapat koordinasi antara Sekolah Vokasi UGM dan Badan Perencanaan Pembangunan Daerah (BAPPEDA) Kabupaten Kulon Progo.

Kawasan perbukitan Menoreh dikarunia keindahan alam yang sangat potensial untuk tujuan pariwisata, terlebih setelah pemerintah pusat menjadikan kawasan ini sebagai kawasan strategis pariwisata nasional. Beberapa potensi wisata diantaranya kebun teh, kebun kopi beserta kedai-kedai kopi, desa penghasil kakao, pembuatan coklat dan hasil olahan coklat, produk olahan susu kambing PE, wisata durian, dan mungkin masih banyak lagi potensi wisata yang belum termaksimalkan pemanfaatannya. Berdasarkan rapat koordinasi dengan BAPPEDA Kulon Progo diketahui bahwa salah satu kekurangan dari wisata kawasan Menoreh adalah masalah promosi. Oleh karena itu pada pengabdian ini kami mencoba memberikan solusi terhadap masalah tersebut. Terutama promosi dan pemsaran produk-produk khas kawasan menorah. Dengan promosi dan pemasaran yang baik diharapkan akan mengenalkan produk-produk khas kawasan menoreh lebih luas lagi dan pada akhirnya akan menaikkan jumlah wisatawan ke wilayah Menoreh.

\section{METODE}

Salah satu desa yang dilewati jalur perbukitan Menoreh adalah Desa Pagerharjo Kecamatan Samigaluh. Desa Pagerharjo ini digunakan sebagai posko pengabdian yang kami lakukan dengan menggandeng Karang Taruna desa tersebut. Namun wilayah pengabdian kami tidak terbatas pada Desa Pagerharjo saja, tetapi mencakup desa-desa lain juga yang ada di kawasan Menoreh. Di desa ini bahkan sudah ada homestay milik penduduk setempat yang dapat menunjang pariwisata kawasan Menoreh. Pada hari Selasa tanggal 21 Maret 2017, kami melakukan survei awal di Desa Pagerharjo dan Kantor Kecamatan Samigaluh untuk memastikan ketepatan tema pengabdian yang dilakukan. Dokumentasi survei ditampilkan pada Gambar 1 dan Gambar 2.

Dibutuhkan solusi konkrit untuk menyelesaikan masalah promosi wisata kawasan Menoreh Kecamatan Samigaluh Kabupaten Kulon Progo. Salah satu solusi yang dapat ditawarkan adalah dengan 
membuat media promosi pariwisata terpadu di kawasan Menoreh. Media yang kami gunakan berupa aplikasi pada smartphone yang berisi informasi pariwisata terpadu di kawasan tersebut. Kementerian Komunikasi dan Informatika Republik Indonesia dalam laman resminya memprediksi pada tahun 2018 jumlah pengguna aktif smartphone di Indonesia melebihi 100 juta pengguna. Dengan jumlah sebanyak itu, Indonesia akan menjadi negara dengan pengguna aktif smartphone terbesar keempat di dunia setelah Cina, India, dan Amerika Serikat. Dari data tersebut dapat dikatakan promosi menggunakan aplikasi pada smartphone adalah salah satu metode promosi yang paling efektif saat ini. Aplikasi berbasis Android yang dibuat diberi nama "Wisata Menoreh".
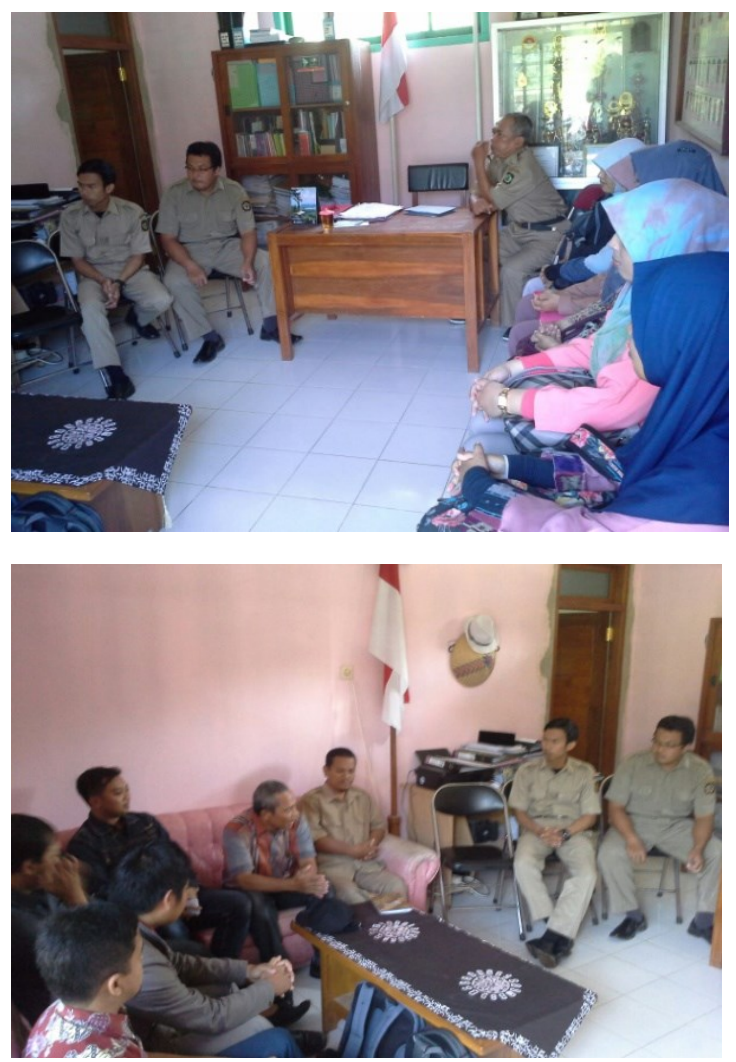

Gambar 1. Rapat koordinasi tim pengabdian dengan perangkat Desa Pagerharjo

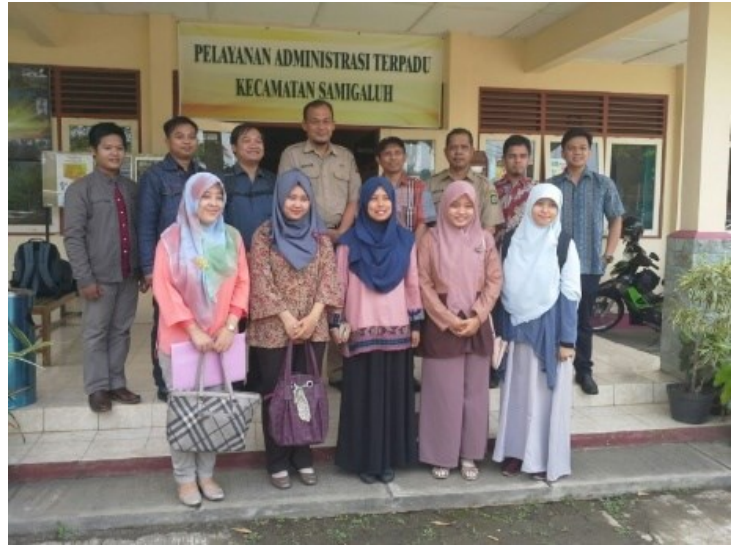

Gambar 2. Tim pengabdian dengan

Camat dan Wakil Sekretaris Kecamatan Samigaluh

Pelaksanaan pengabdian dimulai dengan survei awal tim pengabdian ke lokasi pengabdian, proses ini dilakukan pada tanggal 21 Maret 2017. Dari survei tersebut dihasilkan kesepakatan antara tim dan pihak desa maupun kecamatan mengenai tema pengabdian. Tahap berikutnya adalah pendataan atau pemetaan potensi wisata supaya didapatkan data yang akurat dan aktual. Dalam proses ini tim pengabdi melibatkan lembaga Karang Taruna desa setempat secara aktif. Alasannya karena memang pihak yang paling faham mengenai kondisi wilayah pengabdian adalah masyarakat setempat, dalam hal ini diwakilkan Karang Taruna.

Setelah didapatkan data produkproduk khas kawasan Menoreh, selanjutnya adalah proses pembuatan toko online berbasis web dan pengujiannya. Alokasi waktu yang disediakan untuk pelaksanaan proses ini adalah sekitar dua bulan. Setelah aplikasi selesai dibuat dan diuji, kemudian tim pengabdi akan melatih admin untuk pengaturan sistem. Tahap ini sangat penting untuk dilakukan guna memastikan keberlanjutan operasional toko online produk-produk khas kawasan Menoreh yang dibuat. Pada tanggal 7 Mei 2017 dilakukan sosialisasi dan pelatihan admin Toko Online di balai desa Pagerharjo yang dihadiri perwakilan lima Desa. Lima desa tersebut adalah Pagerharjo, Ngargosari, Gerbosari, Sidoharjo, Purwoharjo. Luaran dari pertemuan tersebut berupa calon admin yang mampu berkontribusi dalam 


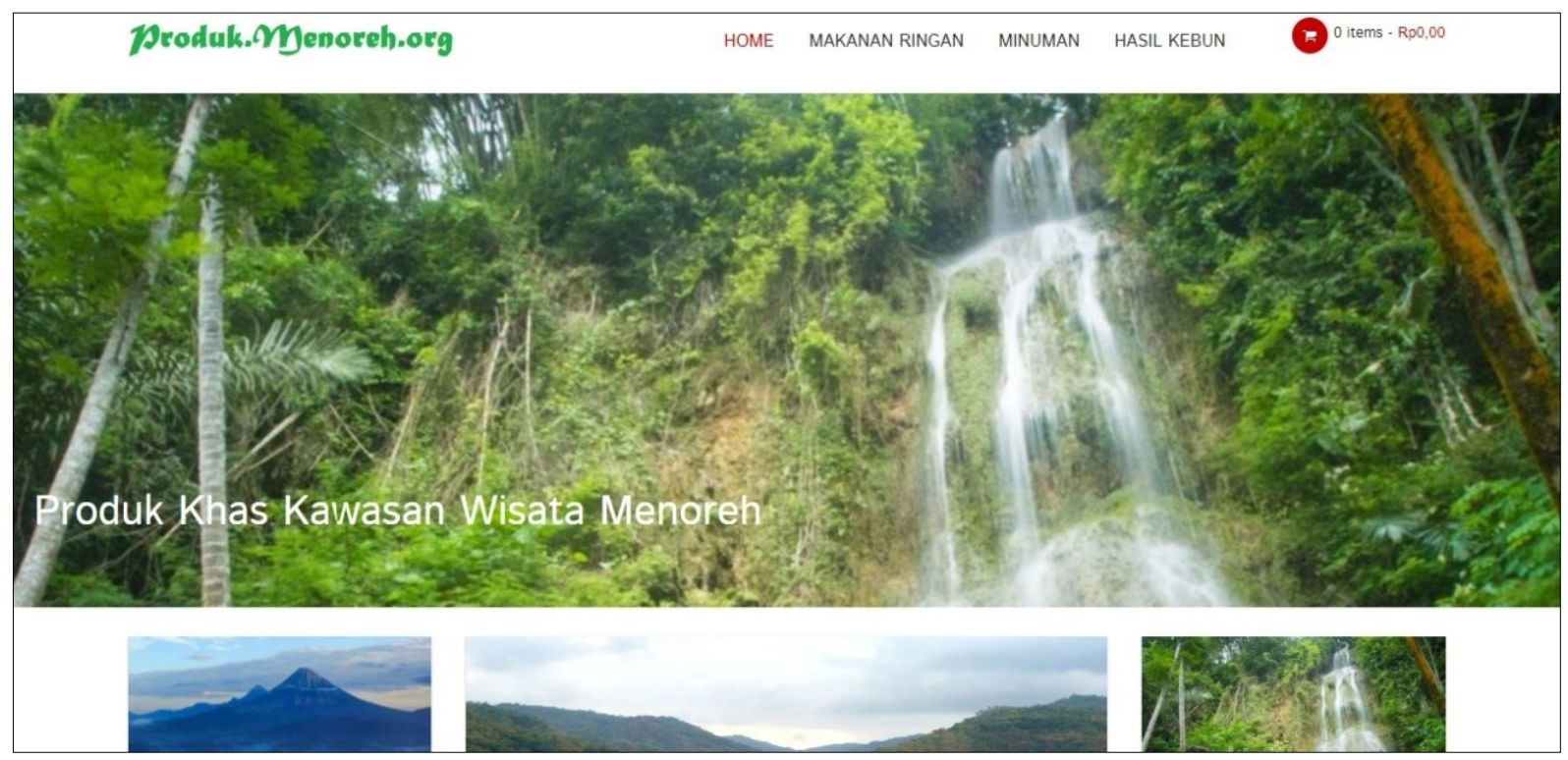

Gambar 3. Tampilan Home

hal menambah atau memperbarui data di aplikasi Wisata Menoreh. Selain itu dalam pertemuan tersebut juga terjadi diskusi yang mengakomodir masukan-masukan dari admin terkait perbaikan Toko Online yang dibuat.

\section{HASIL DAN PEMBAHASAN}

Setelah dilakukan Survey dan Pengumpulan Data yang dibutuhkan untuk membuat Toko Online, Tim akhirnya membuat Toko Online dengan menggunakan CMS (Content Management System) Wordpress dengan berbasis bahasa pemrograman PHP dengan menggunakan database MySQL.

Step Pertama, Tim Membuat Desain Toko Online Produk-Produk Khas Kawasan Menoreh yang meliputi User Admin (Penjual) dan User Konsumen (Pembeli) di Toko Online. Menu Utama dari Toko Online terdiri dari Produk Makanan Ringan, Minuman dan Hasil Kebun.

Step Kedua, Pembuatan Toko Online Produk-Produk Khas Kawasan Menoreh mengacu pada Desain yang telah dibuat. Hasilnya Toko Online dapat kita akses di Alamat URL : http://produk.menoreh.org dengan tampilan Home (User Pembeli) Sebagai Berikut : Gambar 3

Admin / Penjual dari Toko Online juga mempunyai halaman khusus yang dapat diakses di Alamat URL : http://produk.menoreh.org/admin. Pada Halaman ini admin dapat menambahkan fitur yang dibutuhkan oleh pengguna dari Toko Online. Selain itu admin juga dapat menambahkan User Penjual yang lain (di desa masing-masing) yang dapat melakukan posting produk yang dijual. Dalam Toko Online ini, setiap Desa yang ada di Kawasan Menoreh mempuyai 1 admin yang bertanggung jawab menambahkan penjual dan produk-produk khas yang ada di desanya masing-masing. Tampilan Halaman Admin dapat dilihat pada Gambar 4 .

Pada tanggal 7 Mei 2017 bertempat di Balai Desa Pagerharjo dilakukan pelatihan admin Toko Online (lihat Gambar 5.) Diharapkan dengan adanya pelatihan ini, tiap-tiap desa akan dibimbing oleh satu admin untuk memaksimalkan penggunaan Toko Online. Gambar 5. menunjukkan salah satu sesi dalam Pelatihan. 


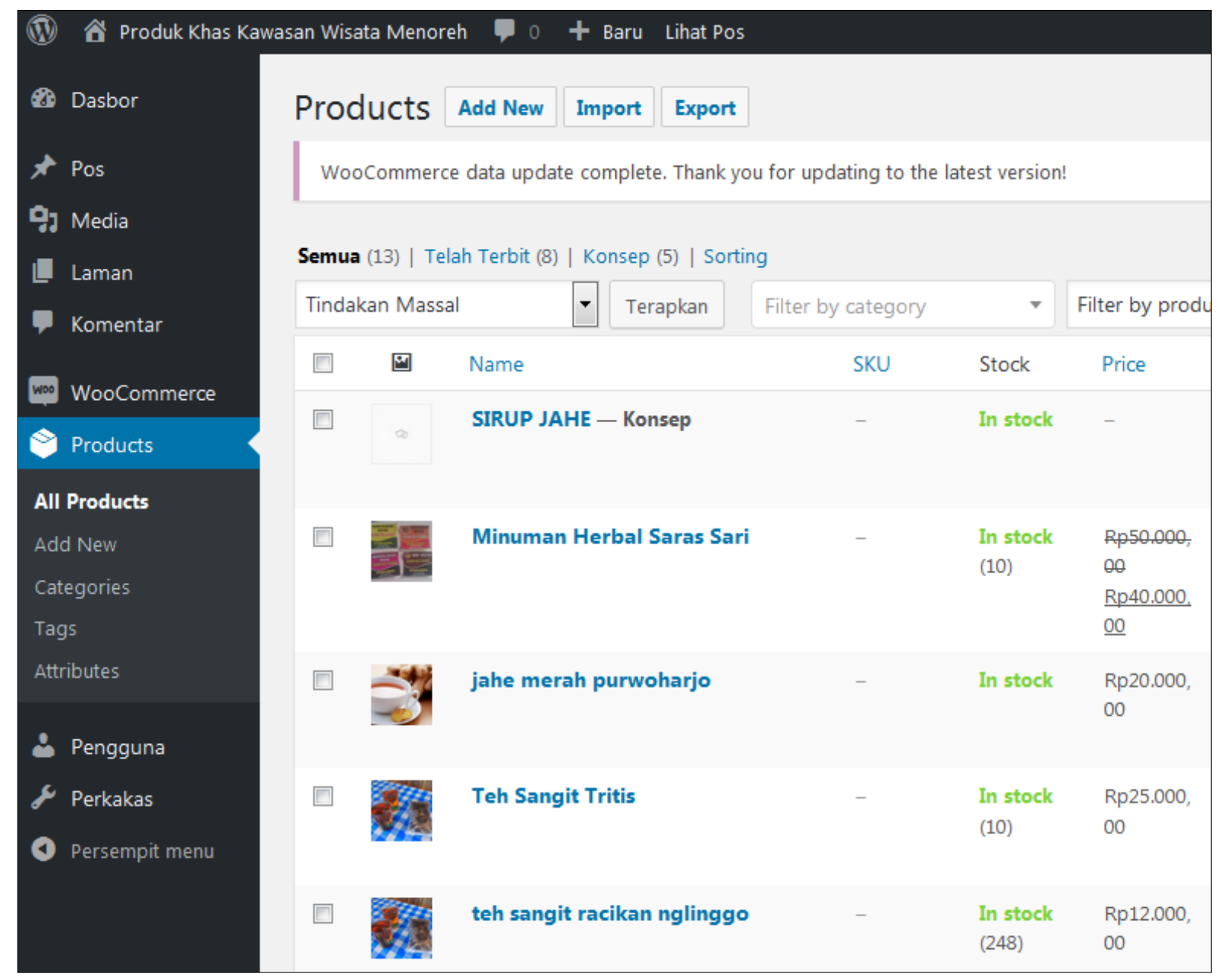

Gambar 4. Tampilan Halaman Admin

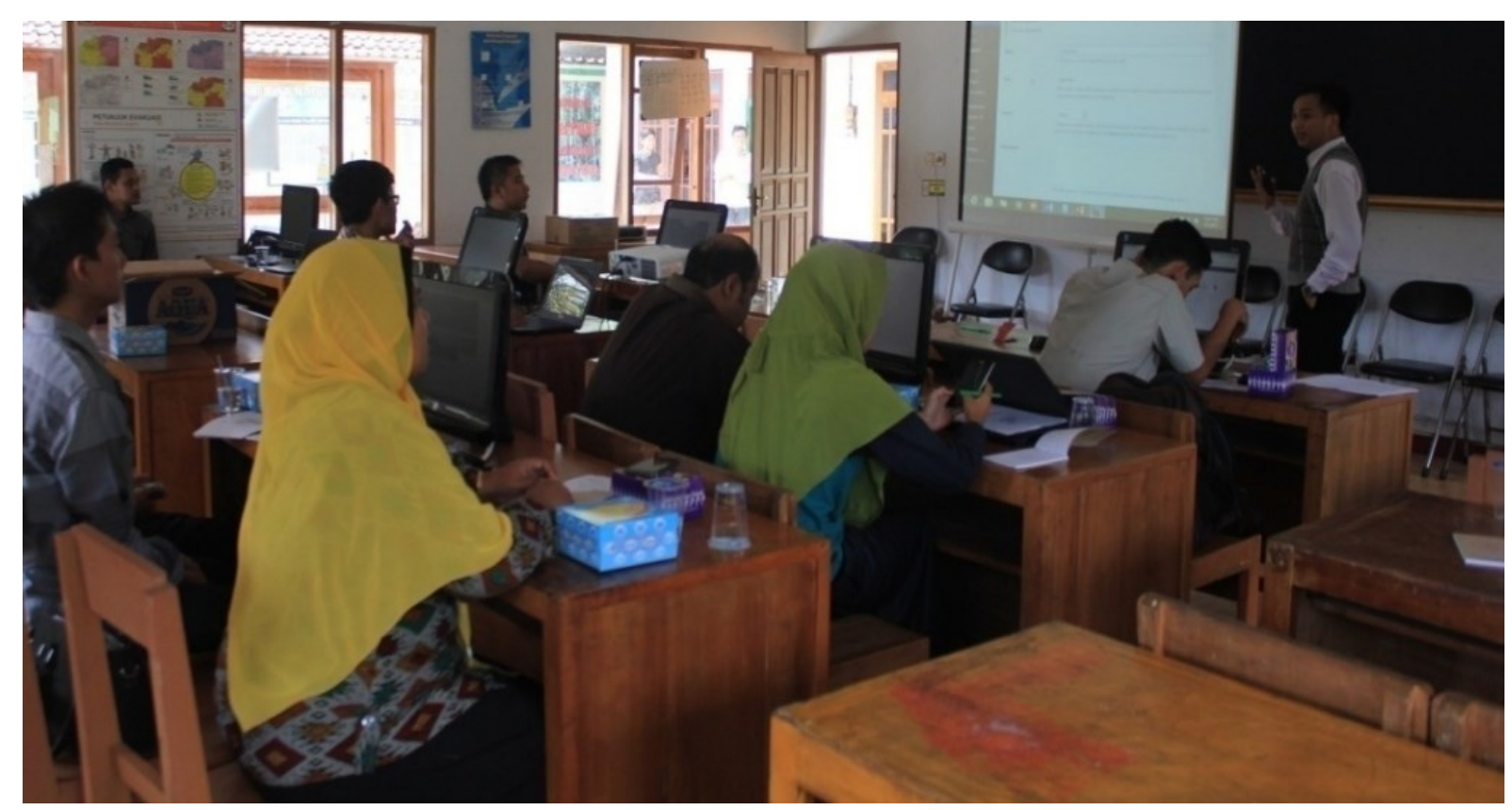

Gambar 5. Pelatihan Toko Online 


\section{SIMPULAN}

Telah dilaksanakan pengabdian kepada masyarakat yang berlokasi di kawasan perbukitan Menoreh Kecamatan Samigaluh Kabupaten Kulon Progo. Pengabdian ini berfokus pada bidang pariwisata. Perbukitan Menoreh menyimpan banyak potensi wisata yang kurang berkembang, salah satu hal yang diindikasikan menjadi penyebabnya adalah kurangnya promosi terhadap tempat wisata tersebut. Setelah dilakukan pengabdian, disimpulkan bahwa toko online yang dibangun mampu membantu dalam memasarkan produk-produk asli kawasan menoreh.untuk kegiatan pengabdian berikutnya.

\section{DAFTAR PUSTAKA}

Pemerintah Kabupaten Kulon Progo. (2012). Rencana Tata Ruang Wilayah Kabupaten Kulon Progo 2012-2032. Wates: Sekretaris Daerah Kabupaten Kulon Progo.

Pemerintah Provinsi Daerah Istimewa Yogyakarta. (2010). Rencana Tata Ruang Wilayah Daerah Istimewa Yogyakarta 2009-2029. Yogyakarta: Sekretaris Daerah Provinsi Daerah Istimewa Yogyakarta.

Presiden Republik Indonesia. (2011). Peraturan Pemerintah Republik Indonesia Nomor 50 Tahun 2011 Tentang Rencana Induk Pembangunan Kepariwisataan Nasional Tahun 2010 2025. Jakarta: Kementerian Hukum dan Hak Asasi Manusia Republik Indonesia .

Dadang Rizki Ratman (Deputi Bidang Pengembangan Destinasi dan Investasi Pariwisata). (2016). Pembangunan Destinasi Pariwisata Prioritas 2016 - 2019. Jakarta: Paparan Deputi yang disampaikan pada Rapat Koordinasi Nasional Kementerian Pariwisata.

Maryanto, D.A. (2007). Candi Borobudur. Yogyakarta: Citra Aji Parama. 